\title{
Translating degrowth into contemporary policy challenges: a symbiotic social transformation strategy
}

\author{
MARY P. MURPHY \\ Department of Sociology, NUIM
}

\begin{abstract}
Wright poses us the challenge of building a world of equality while working in the world of today. This article addresses the challenge of transitioning to a degrowth economy and eco-socialism which focuses on distribution over production and which requires a strong ethic of equality at the heart of society. Degrowth aims to address over-consumption by addressing real need, reducing wants, ensuring greater distributive equality and ultimately by suppressing production. However, the detailed mechanisms of how a steady-state economics can provide a quality of life and employment, eliminate poverty and promote an egalitarian society require immense work to flesh out. This article points in the desired direction of travel and outlines some initial steps. It fleshes out two key obstacles to degrowth, the issue of employment and the impact for revenue and expenditure arising from a move towards degrowth. It points to the relevance of degrowth arguments for feminist and democratic movements and how the degrowth strategy offers potential for new political coalitions. It concludes by reflecting on the limitations of symbiotic transformative strategies and the need for a language capable of imagining and articulating real utopias.
\end{abstract}

Key words: degrowth, eco-socialism, employment, care, political alliances, imaginaries

\section{Introduction}

Wright (2013) identifies two foundational principles for alternatives:

- an egalitarian principle of social justice where in a socially just society, all people would have broadly equal access to the social and material means necessary for living a flourishing life;

- a principle of radical democratic empowerment where, in a fully democratic society, all people would have broadly equal access to the necessary means to participate meaningfully in decisions about things 
which affect their own lives as separate persons, and their capacity to participate in collective decisions which affect their lives as members of a broader community

Taking such democratic egalitarian principles seriously requires moving beyond capitalism and the question for Wright is how best to theorise the alternative that would better enable the realisation of such democratic egalitarian principles. An economic structure can be more or less capitalist, more or less socialist, more or less statist and different alternatives for transformation or institutional innovations can be located within three broad configurations, each of which corresponds to different political traditions of socio-economic transformation: a socialist cluster, a social economy cluster and a social democratic cluster. All engage to some degree or other in shifting social power and moving towards equality and social justice and environmental sustainability. Core to transformation is a shift in power relations over economic activity, both in terms of the ways social power is directly involved in shaping economic activity and indirectly through the democratisation of the state. For Wright transformation depends on the ability to enlarge and deepen the 'social' and statist component of the hybrid and weaken the market component.

Transformation requires understanding the ways in which strategies of transformation have some prospect in the long term of eroding capitalist power relations and building up socialist alternatives. Wright identifies three strategic logics of transformation that have characterised the history of anti-capitalist struggle: ruptural transformations envision creating new emancipatory institutions through a sharp break with existing institutions and social structures. Interstitial transformations seek to build new forms of social empowerment in the niches, spaces and margins of capitalist society. These potentially erode the constraints on the spaces themselves but also serve a critical ideological function of showcasing alternatives. Symbiotic transformations deepen the institutional forms of popular social empowerment while simultaneously helping solve certain practical problems; 'non-reformist reforms' simultaneously make life better within the existing economic system but expand the potential for future advances of democratic power.

Wright concludes that the appropriate orientation towards strategies of social transformation is to do things now which put us in the best position to do more later, to work to create those institutions and structures which increase, rather than decrease, the prospects of taking advantages of whatever historical opportunities emerge. He concludes the best prospect is a strategic package mainly organised around the interplay of interstitial and symbiotic strategies, with episodic aspects of ruptural strategy. This article explores policy reforms in Ireland that could potentially move us in meaningful ways towards eco-socialism and is firmly in the symbiotic transformative mode aiming to simultaneously make life better within the existing economic system but expand the potential for future advances of democratic power or, as Wright puts it, 'to take the first step'. 
Degrowth addesses over-consumption measures that can suppress production. This can mean addressing the construction of wants through controls of advertising but central to all conceptions of a degrowth economy and eco-socialism is the primacy of distribution over production, thus involving a strong ethic of equality at the heart of society. However, the detailed mechanisms of how a steady-state economics can provide a quality of life and employment, eliminate poverty and promote a radical egalitarianism, require immense work to flesh out. Given the scale of the task there are no blueprints, nor should there be; rather the challenge Wright poses is to point in the desired direction of travel and take the first steps. The remainder of this article attempts to flesh out two key obstacles to degrowth, the issue of employment and the impact for revenue and expenditure arising from a move towards degrowth. It points to the relevance of degrowth arguments for feminist and democratic movements, how these movements can contribute to degrowth agendas and how the degrowth strategy offers potential for new political coalitions. The conclusion reflects on the capacity and limitations of symbiotic transformative strategies and the need to develop a language capable of imagining and articulating real utopias.

\section{Jobs and degrowth}

In discussing why sustainable development has failed, Smith observes that no government will realistically impose 'green taxes' or degrowth strategies that might drive industries out of business (Smith 2011: 117). Addressing overconsumption by forcing major retrenchments or suppressing production would, in a capitalist system, hasten recession and mass unemployment. There are clear obstacles to the type of eco-socialism and degrowth strategies described in Kirby's article in this special edition. The most obvious, particularly in a time of high unemployment, is the perceived negative relationship between degrowth and levels of employment.

We should not underestimate or overestimate the degree to which a focus on reducing the imperative for growth will impact on jobs. The growth imperative in capitalism is not to produce goods per se, it is to make profit or to accumulate capital. Financialised capital can realise profits without any tangible or virtual production or service. Likewise there are many ways profit can be made without material production or consumption, including recreational services, sports, movies, opera, internet services, albeit these involve some level of carbon emissions. Galbraith (2008) writes that only 17 per cent of employment is required to service production thus showing that shifting employment away from production will not hit a large proportion of today's labour force (although his argument is based on post-industrial Western developed economies). It is possible therefore to imagine opportunities for radical restructuring that do not have to involve large-scale unemployment. Alternative paradigms will involve a shift from jobs that produce 'goods' for consumption to jobs that maintain 
goods for use. The focus in Smith's words has to 'be on shareable and durable goods', avoiding built-in obsolescence and developing a renewed emphasis on the commons (Smith 2011). Davis argues that we have the technology to create the goods we need with just a minimal input of labour, that economic crisis offers the possibility of a large-scale restructuring of both public and private sectors and that there is much to learn from new forms of organising production (Davis 2012: 36).

That said, significant levels of profitable investment, capital accumulation and growth are derived from growth in material production or exploitation of natural resources with significant implications for greenhouse gas emissions. As Smith argues, 'capitalism means perversely, that it is in the general interest, in everyone's immediate interests to do all we can to maximise growth right now, therefore, unavoidably, maximising fossil fuel consumption right now because practically every job in the country is, in one way or another, dependent upon fossil fuel consumption' (Smith 2011: 122). As Trainer argues, drastic contraction of production in the industrialised countries, especially in the most polluting industries, implies large-scale reductions in the volumes of economic production and consumption taking place with implications for living standards, for maximum levels of economic output, and for economic growth (Trainer 2010). Indeed many radicals have at this time of austerity become at least temporary advocates of growth. Even though they are not avid supporters of consumer capitalism, they are acutely concerned about the human tragedy of unemployment. Gillespie (2013) raises the apparent folly of cries for degrowth at a time when 'glimmers of growth' are appearing and when people are hopeful that growth might offer a route out of recession and austerity in most developed countries.

Writing in a contemporary South African context, Cock (2011) is realistic about how fears of job loss can impact on the capacity to build alliances between environmental and trade union movements and she cautions realism in the debate. She argues against large inflated claims about green jobs that are not supported by empirical evidence, and urges greater attention to the quality of green jobs in terms of labour standards and wage levels. She also places greater emphasis on the degree to which green jobs are actually green and she acknowledges that there will be significant job losses. Nonetheless she is clear that it is possible to develop an agenda for publicly supported decent and useful green jobs that meet social needs (Cock 2014). To create green, decent, useful jobs in renewable energy requires state intervention, at least in the form of supportive policies such as tax rebates, local content criteria and regulations. Localisation of agro-ecology could address food security issues, the unemployment crisis and the environmental crisis at the same time. The local state could accelerate this kind of intervention by changing its procurement policies to require state institutions to procure a proportion of their food requirements from local suppliers. She crucially emphasises the win-win nature of such an 
approach: 'Green jobs in these two areas: renewable energy and urban agriculture, can help us address all of the three crises we face - the crises of climate, unemployment and food security - in the immediate term' (Cock 2011: 241). The United Nations Environmental Programme (UNEP) defines green jobs as 'those in existing and new sectors which use processes and produce goods and services aimed at alleviating environmental threats' (UNEP 2011: 66). Cock argues that this emphasis on the creation of 'green' or 'climate jobs' challenges the false dichotomy which portrays labour-environmental relations as a trade-off between jobs and the environment. Also, in acknowledging the reality of job loss, the UNEP demonstrates the need for appropriate measures to guarantee a fair transition for potentially affected workers including social protection systems that can diminish vulnerability to climate change, economic diversification policies and training and requalification programmes.

Translating this into a European debate, the New Marshall Plan for Europe compares the employment effects of oil and gas imports to an energy supply that is low in carbon emissions. High-carbon oil industries currently support 2.4 million jobs and high-carbon gas industries support 3.6 million jobs. EU estimates for low-carbon energy jobs include 17 million energy-efficiency jobs, 10-11 million jobs in renewable energy and 16 million jobs in transport infrastructure. They concur that 'a fundamental overhaul of European national economies in terms of energy policy would yield between 9-11 million new fulltime and innovative jobs' (ICTU 2014: 9).

There is a strong correlation between annual working hours and ecological outcomes: indeed one outcome of the reduction in aggregate working hours caused by recession-related unemployment has been the easier attainment of carbon goals. Gough argues there are direct environmental gains from the reduction in aggregate demand that would result from a reduced working week (Gough 2013). Reduced income will directly reduce consumption and more time available for personal life can alter the composition of consumption towards lower carbon-intensity products and lifestyles. While the overall logic and rationale of such an argument is strong, there are clear distributional, class and gender dilemmas in how a policy shift towards reduced working hours would play out. Reduced working hours for women are already a cause of gender pay gaps and pay inequality. European labour markets are increasingly characterised by the presence of jobless or low-work intensity households alongside job-rich or high-work intensity households. There is the risk of poverty among the low paid, of dual labour markets based on different levels of work intensity, and therefore higher levels of precarious work practices. Taxation, social and labour market policies would have to adequately address issues of in-work income support and incentives for both employees and employers.

Any successful argument for degrowth or any discussion of the relationship between labour market strategies and growth has to engage with the issue of how people access employment, and how the resource of paid work and the 
reciprocal obligation of unpaid care work can both be shared more equally. Degrowth is not about the 'end of work', but it does look at the type, quality and distribution of work. It is concerned with who has the jobs, the working week, job quality, care, life-long learning and work autonomy. This should involve a focus on the distribution of work (paid and unpaid), care (paid and unpaid) and income. This implies an emphasis on service and care work and local provisioning. Gough argues that there are already interesting lessons in strategies aimed at reducing working time (Gough 2013). Various countries, including Germany, have reduced the working week as a strategy to manage the crisis and are experimenting with new forms of limiting working time. A 2014 Swedish pilot project is experimenting with six-hour working days in city councils and France has recently curtailed employers' invasion into staff's social and private time between 6p.m. and 9a.m. while also banning work from 9p.m. to 6a.m. unless that work plays an important role in the economy or has clear social benefit (Slattery 2014). There is a growing awareness that work or human labour has an ecological footprint. The EuroMemo group (2013) argues for a 30-hour week and for a 21-hour week in challenging the fetishism of growth. Despite the crisis there is passion in the labour movement for the slogan 'working shorter to live longer' (Passchier 2014).

\section{Taxation}

A second obstacle to degrowth is the fear of lost revenue and a lost capacity to fund the level of social investment required to achieve degrowth and support even minimal social standards within an eco-socialist or even social democratic model. The current crisis has already highlighted the degree to which Ireland's contemporary taxation system is over-reliant on income taxation as a source of revenue. This means, at least in the short-term, an anxiety about the degree to which changes in the composition and distribution of employment might impact on taxation. An obvious obstacle to lowering the number of total hours worked in paid employment is the implication for revenue generation and the impact on overall fiscal sustainability. Who will pay the taxes for services and who will pay for the public sector jobs and large state infrastructure envisioned in an ecosocialist economy?

To begin with, we know little about what impact a major redistribution between paid employment on the one hand, and unpaid and community work on the other may have on our well-being. There remains the possibility that, especially in the longer term, education, health and housing costs will be lower and there will be less stress on public expenditure. However, even if we expect government expenditure to remain at approximately similar levels of GDP (which in the Irish case is relatively low) we do need to find ways to replace employment-related taxation as a primary source of revenue. Ungar (2013) identifies various sources of income that EU member countries could use to 
invest in social policies. While necessarily brief, this section highlights four potential sources of revenue that remain underrealised in capitalist regimes: financial transaction taxes, wealth taxes, production and energy taxes and consumption taxes.

The recent financial crisis has renewed interest in a financial transactions tax (FTT). According to the Nevin Institute (2013), an FTT would allow states to more adequately monitor the financial sector, provide additional taxation revenue, and reduce the volume of high-risk financial transactions. The European Commission and Parliament have proposed an FTT which is being implemented in twelve member states; such an FTT would be structured to capture activities in all markets, through all instruments and among all actors. Estimates for the potential yield vary widely with ICTU estimating a range of from $€ 70$ billion to $€ 320$ billion for an FTT that covered all derivatives and foreign exchange (ICTU 2014). The Nevin Institute (Collins 2013) makes a conservative claim that an FTT could raise $€ 34$ billion each year and that this could address poverty and inequality by funding quality public services while curbing intense speculative trading. To date, Ireland has been unwilling to support the FTT proposal which could produce a net tax gain of between $€ 300-550$ million per annum for Ireland but there are active campaigns with Irish civil society towards this end.

Globally Ungar (2013) estimates that the amount hidden in private and corporate legal tax avoidance measures and illegal tax evasion methods to be up to US\$32 trillion in offshore financial assets. Focusing on one country as an example, she suggests that taxing only 0.2 per cent of the richest Germans by 1 per cent of their wealth would result in an annual tax revenue of $€ 8.9$ billion (Ungar 2013: 97). Corporation tax is a potential source of revenue, with the global focus on the need to address glaring tax loopholes in taxing multinational corporations, and there is extensive scope for Ireland to reform its corporation taxes. The capacity of individuals and corporations to engage in serious tax avoidance and evasion strategies means there are serious limitations to national wealth taxation strategies. Picketty (2014) proposes overcoming avoidance and tax mobility through a global progressive tax on individual net worth which would be internationally coordinated to manage tax avoidance. In the same vein ICTU (2014) join other European unions in calls for a regional EU level wealth tax of 3 per cent on all wealth in excess of $€ 500,000$ for single and $€ 1,000,000$ for married couples which has the capacity to raise $€ 200-250$ billion across Europe. Galbraith dismisses such ideas as utopian:

$[\mathrm{T}] \mathrm{o}$ begin with, in a world where only a few countries accurately measure high incomes, it would require an entirely new tax base, a worldwide Domesday Book recording an annual measure of everyone's personal net worth. That is beyond the abilities of even the NSA. And if the proposal is utopian, which is a synonym for futile, then why make it? (Galbraith 2014: 1)

There are ways to tax wealth. At a domestic level we can think in the first instance about how to maintain or increase tax revenues from existing levels 
of productivity and without increasing taxes on labour. This can be done by focusing on the wealth of the top 10 per cent or even 1 per cent of the income and wealth hierarchies. In an Irish context, Collins proposed ways to gather up to $€ 1$ billion without significant impact on investment but with significant impacts on distribution and on income equality, including gender equality (Collins 2013). Measures such as wealth taxes, employers' social insurance taxes, changes to existing income tax reliefs and exemptions, corporation taxes, capital gains taxes and capital acquisition taxes, demonstrate significant opportunities to increase revenue by redistributing existing resources. Such an approach is consistent with 'challenging the place of the rich' (Sachs 2013: 27). Given the degree to which wealthy Irish nationals already live as tax exiles, the possibility of tax flight needs to be taken seriously. However, the room for manoeuvre in increasing some forms of wealth tax was demonstrated over the crisis when various initiatives to tax wealth flow were successfully implemented, including a doubling of capital gains taxes, capital acquisition taxes and the introduction of a property tax.

The third avenue to addressing revenue shortfalls is taxing production and specifically taxing environmentally damaging forms of production that use disproportionate energy, especially non-renewable energies. It is appreciated that such taxes need very careful design and a global implementation strategy if they are to work. Herman Daly makes a compelling case for shifting from income taxation to forms of resource taxation in the form of ecological taxes (Daly 2007). This necessarily entails protecting remaining commons and limiting the further expansion of the economy into the eco-system, what in Polanyian terms would result in a decommodification of nature. Ecological tax reform means imposing taxes at the source of depletion of the natural resource. Daly argues that such taxation reflects the necessary valorisation price or scarcity rent that we place on scarce environmental public goods, it raises resource prices and encourages more efficient use of such scare resources in both production and consumption. Regressive impacts can be lessened by ensuring that revenues raised from such taxation would be used to alleviate poverty and finance the provision of public goods.

The fourth arena for taxation is to shift towards taxing the consumption of goods, and particularly towards taxes that can produce behavioural changes in what we consume and how we consume. These are not new ideas (and have been around for a long time in relation to smoking and tobacco). Artificial demand could also be dampened by high taxes on advertising (indeed we could go further by banning billboard advertising as was done in Vermont, Hawaii, Maine and Alaska and banning advertisements of children's toys). The focus for consumption taxes should be on luxury goods and goods entailing high emissions. Such taxes serve to modify preferences and consumption behaviour and to constrain total consumption demand. However the broader use of consumption taxes on more everyday goods may also be necessary, but this raises distributional dilemmas. There are potentially significant regressive impacts 
from non-luxury goods consumption taxes, so that they need to be modified or complemented with creative social policy that can mitigate regressive impacts. Gough makes a novel argument for an 'eco social policy'; forms of proactive social investment alongside climate mitigation policy so that environmental and social policy goals complement rather that contradict each other (Gough 2013: 191). Compensating social policies can include direct income compensation like fuel payments, reduced energy bills through variable energy prices, and thermal efficiency policies like retrofitting. He argues that addressing energy efficiencies is the preferred policy option, it is most tightly targeted and is closely aligned with ecological goals.

The concept of tax justice or using tax policy to achieve ecological and social justice goals can be dismissed as utopian but this is also to dismiss the growing social power behind demands for tax justice. Marshall (2013) celebrates high-profile Robin Hood Tax rallies during 2012 G8 and Rio+20 Earth summits and campaigns in countries as diverse as Brazil, the United States and South Africa. The Global Alliance for Tax Justice was formed early in 2013, and 'tax justice for social justice' was the call at the World Social Forum in Tunisia in March 2013 when 240 leading civil society and labour organisations signed the Fair Share Commitment on World Public Services Day 2013. Taxation has the potential to generate the type of cross-class and cross-sector alliances that McCabe (in this special issue) argues are necessary to challenge power and achieve transformation.

\section{Equality and democracy}

There is a strong gender dimension to this debate and degrowth debates overlap with the policy agendas that seek to accommodate and redistribute care work. Schultz and Hoffman advocate the restructuring of and reduction in working time to decrease stress, increase gender equality in working time, and facilitate the achievement of work-life balance (in Fudge and Owens 2006). They argue that stronger employee representation, more effective government monitoring and enforcement capacity, and the creation of norms which allow and encourage reduced working time would advance this agenda. The framework in Figure 1 is useful in visioning alternative ways to share and balance reproductive care and productive work, to understand how they interrelate, and to analyse how to break patterns of path dependencies.

At stage one, typologies like 'male bread winner' or 'modernised male breadwinner' reflect deeply differentiated gender roles where women perform 'wifely labour' (Shaver and Bradshaw 1995). In stage two, 'mother /worker' models reinforce gender differentiation while acknowledging the dual roles women undertake as mothers or carers, and increasingly as workers. In stage three, 'adult worker' models see both adults in paid employment and purchasing commodified care, similar to what Fraser (1994) terms 'universal breadwinner'. 
Figure 1: Typologies of gendered work/care combinations

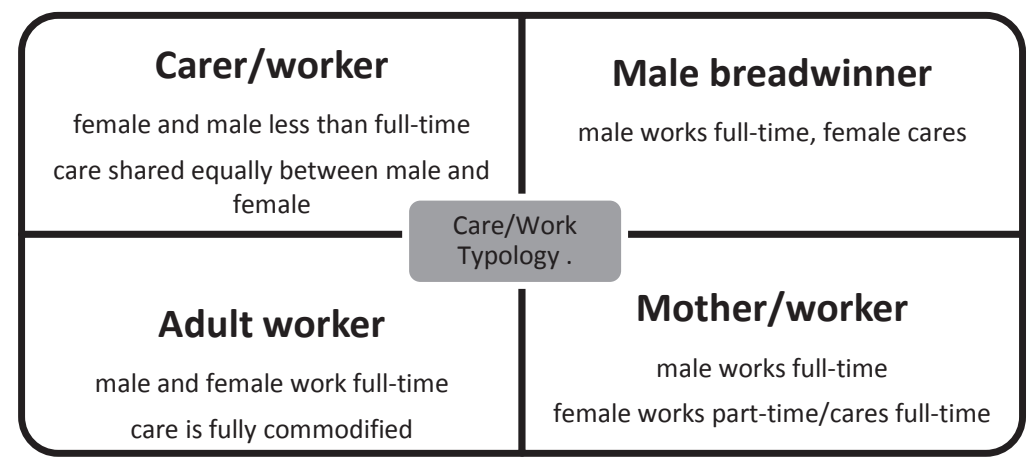

Stage four, the 'carer /worker' model, is a feminist approach informed by a care ethic and the concept of affective equality, and greater sharing between men and women of both care and paid employment (Hobson 2003). This approach is similar to both Fraser's 1994 seminal approach and her universal care-giver, as well as the European concept of the individual carer-earner regime (Sainsbury 1999) which includes well-developed gender-equality friendly policies (Sorensen and Bergqvist 2002). The focus on accommodating work and care for mothers and fathers implies a residual need for care which may be provided by the market or the state. It requires state policy to enable sharing of care with intervention at the level of the family and the market to promote family-friendly policies for both men and women, as well as the promotion of male care roles through paid parental leave (Lewis and Guillari 2005).

Restoring democratic power and economic power are intrinsically linked and if degrowth can create time in people's lives it can also serve to enhance democratic participation in the workplace. Schultz argues for a third path in which we not only redistribute care roles between men and women, so enhancing gender equality, but also increasing our capacity to invest our time in our imaginaries. As she argues, 'spinning in the overwhelm keeps us from having the time to imagine a way out of it' (Schultz 2013). What is needed are further imaginaries or thought experiments along the lines of Fraser (1994) that enable us to see the possible combination of work, care and time for democracy and flourishing human relations that can realise Wright's (2013) foundational principles for alternatives: an egalitarian principle of social justice and a radical principle of democratic empowerment can be best realised by reimagining the fundamental place of care, work, democracy and flourishing in our lives. This gives rise to the possibility of new political coalitions including intersectional coalitions of labour, gender, environmental and democracy movements of a scale sufficient to generate a new politics as shown in Figure 2. 
Figure 2: Cross-sectional spaces triggered by degrowth

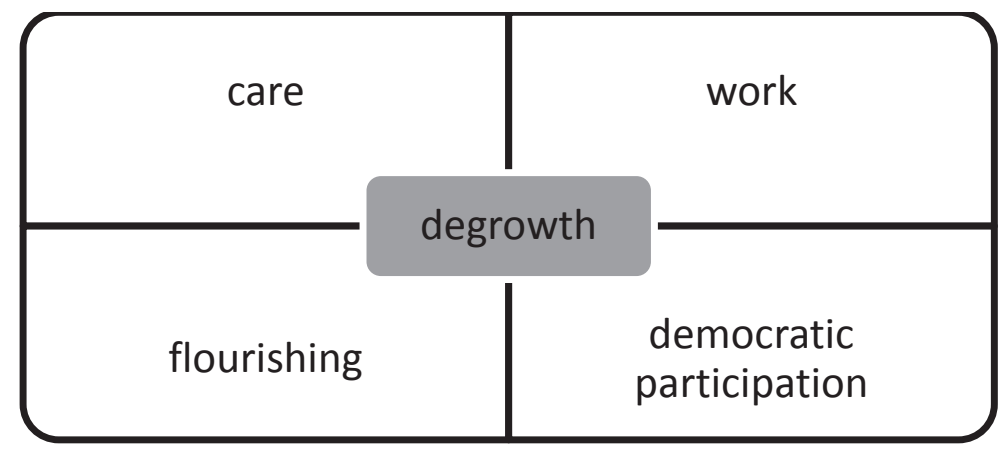

As with environmental taxes, eco-social policy has a key symbiotic role to play. The choice to work 'part time' can be supported through changes in employment regulations (as in the Netherlands and Austria). Change in social welfare regulations and provisions can facilitate new forms of work (as in the Nordic countries). Tax reform with refundable tax credits can better support low-income workers (as in some OECD countries). Redistribution of domestic and social care work across genders can be encouraged through paid paternal leave (as in Sweden and Germany). Investment through state strategies will be required to fund and implement these alternatives. Social investment, as seen in the EU Social Investment Package (EC 2013), is needed to focus on employment in childcare, preventative social services, education and training, housing and health provision. Committing a percentage of the EU budgets to social investment needs to be a core part of the strategy (EuroMemo Group 2013).

\section{Conclusion: restating the case for transformation}

The central challenge of an ecological socialism, or an economy for the common good, is to curb the imperative of economic growth that is the central driver of today's market economy while at the same time maintaining forms of investment and distribution capable of sustaining jobs and adequate income. However there are not only limits but also dangers in symbiotic transformational strategies for degrowth in that they are nested with capitalism and can also work to reinforce rather than transform the status quo. As McCabe observes in this special edition, symbiotic transformational strategies are vulnerable to the capacity of capitalism to reinvent, usurp and refashion potentially symbiotic changes for its own ends. Thus strategies that focus on reduced working time have the capacity to be manipulated into strategies that support precarious part-time work and that do nothing to alter consumption and production patterns, but can do much to 
undermine equality and disempower workers. The challenge is to see how far it is possible to maintain an economic system as a system of hybrid ecosystems, how far counter-capitalist processes can neutralise in a meaningful way some of the harms of capitalism without a fundamental kickback from capitalism. Symbiotic reforms genuinely matter in their own right, but they also serve as platforms for pushing more radical change. We can only speculate as to the threshold at which symbiotic strategies require the elimination of capitalism as the necessary condition for their own existence.

All this requires significant transformation. As Smith rightly points out 'under capitalism, industries can't be expected to voluntarily commit economic suicide, even to save the humans' (Smith 2011: 118). Rather this will only happen in the context of a significant transfer of power from the market to the state, but especially to the social. Cock (2011) argues this requires a shift from focusing on 'thin' change, on protecting the most vulnerable workers and the poor, as has been the focus of social democratic and developmental states in this period of crisis. Instead, it requires an agenda of deep substantive change in the ways we produce and consume, to create a more just and sustainable social order, developing an alternative socialist order built on public ownership and democratic control. From this perspective the climate crisis provides the opportunity to demonstrate that the cause of both climate change and economic crisis is the expansionist logic of the capitalist system. She argues for an alternative anti-capitalist development path and that a 'just transition to a low carbon economy' could contain the embryo of an alternative eco-socialist order. This is consistent with Harvey's insight that 'an ethical, non-exploitative and socially just capitalism that redounds to the benefit of all is impossible. It contradicts the very nature of what capital is' (Harvey 2010: 239).

Massey reminds us that the vocabulary we use to talk about the economy is a political construction that needs contesting; in developing the dominant hegemony, the right changed the public use of economic language and thus collective world-views. For political contestation to take place, we need to question how we think about the economy, in Massey's words, 'for something new to be imagined, let alone to be born, our current economic "common sense" needs to be challenged root and branch' (Massey 2013: 15). New socialism emphasises the development of human beings and the satisfaction of social needs through workers' control, and democratic participatory forms of production. Cock advises that to arrive there requires rethinking how we produce and consume, rethinking how we relate to nature and each other and requires us rethinking how we understand human nature (Cock 2011). She (2014: 23) points to the South African experience of alliances between the labour and environmental movements, which while historically disconnected and even antagonistic, have recently created new solidarity networks to promote radical alternatives. She describes unions' attempts to formulate environmental policies and joint action on 'climate jobs' and rising electricity prices, and concludes 
this has the capacity to create new political alliances. She concludes that these could generate a new kind of transnational solidarity, larger, deeper and more powerful than anything we have yet seen (Cock 2014: 40).

Our choice of language and words impacts on our capacity to develop alliances around shared images of the future. For some, degrowth is the wrong debate when the contemporary challenge is to tackle high unemployment; for others eco-socialism conjures up images of too strong state power at the expense of human emancipation. However if translated into core basic concerns like care work, gender equality, democracy and time, the possibilities offered by degrowth and the compass setting it offers for the first step in a longer journey can be made meaningful to a wider group.

\section{References}

Cock, J. 2007. The War Against Ourselves: Nature, Power and Justice. Johannesburg: WITS University Press.

Cock, J. 2011. 'Labour's response to climate change', Global Labour Journal 5(3): $235-42$.

Cock, J. 2014. 'The "green economy": a just and sustainable development path or a “wolf in sheep's clothing"?' Global Labour Journal 5(1): 23-44.

Collins, M. 2013. 'Tax justice alternatives for Budget 2014', Presentation to 'Claiming Our Future' conference, Croke Park, 13 July 2013.

Coote, A., A.J. Franklin and A. Simms 2010. 21 hours: Why a shorter working week can help us all to flourish in the 21st century. London: NEF.

Daly, H.E. 1991. Steady-State Economics. Washington DC: Island Press.

Daly, H.E. 2007. Ecological Economics and Sustainable Development: Selected Essays of Herman Daly. Cheltenham: Edward Elgar.

Davis, G.F. 2012. 'How financial markets dissolved the society of organizations', Rassegna Italiana di Sociologia 53(1): 13-42.

EuroMemo Group 2013. The Deepening Crisis in the European Union: The Need for a Fundamental Change. European Economists for an Alternative Economic Policy in Europe. Brussels: EuroMemo Group.

European Commission (EC) 2013. Towards Social Investment for Growth and Cohesion - Including Implementing the European Social Fund 2014-2020. (20 February) $\operatorname{COM}(2013) 83$ final. Brussels.

Fraser, N. 1994. "“After the family wage": gender equity and the welfare state', Political Theory 22(4): 591-618.

Fudge J. and R. Owens (eds) 2006. Precarious Work, Women, and the New Economy: The Challenge to Legal Norms. Oxford: Hart.

Galbraith, J. 2008. Predator State: How Conservatives Abandoned the Free Market and Why Liberals Should Too. New York: The Free Press.

Galbraith, J. 2014. 'Kapital in the $21^{\text {st }}$ century', Dissent: A Quarterly of Politics \& Culture (Spring). www.dissentmagazine.org/article/kapital-for-the-twenty-firstcentury, accessed 7 July 2014.

Gillespie, P. 2013. 'Saving the planet, saving ourselves', Irish Times, 21 August.

Gough, I. 2013. 'Carbon mitigation policies, distributional dilemmas and social policies', Journal of Social Policy 42(2): 191-213.

Harvey, D. 2010. The Enigma of Capital and the Crises of Capitalism. New York: Advocacy Initiative. 
Hobson, B. 2003. 'Squaring the circle? The individualised worker, the gender participatory and the gender equity models in Sweden', Social Policy and Society 3(1): $75-83$.

Irish Congress of Trade Unions (ICTU) 2014. The New Marshall Plan for Europe. Dublin: ICTU.

Jackson, T. 2009. Prosperity without Growth: Economics for a Finite Planet. London: Earthscan.

Kirby, P. and M.P. Murphy 2011. Towards a Second Republic: Irish Politics after the Celtic Tiger. London: Pluto Press.

Lewis, J. and S. Guillari 1995. 'The adult worker model family, gender equality and care: the search for new policy principles and the possibilities and problems of a capabilities approach', Economy and Society 34(1) 76-104.

Marshall, T. 2103. Its Time To Demand Our Fair Share. www.advocacyinitiative.ie/ discuss/2013/10/29/its-time-to-demand-our-fair-share/, accessed 7 July 2013.

Massey, D. 2013. 'Vocabularies of the economy', pp. 1-16 in S. Hall, D. Massey and M. Rustin, After Neo Liberalism the Kilburn Manifesto. London: Soundings L.W. Books. www.lwbooks.co.uk/journals/soundings/manifesto.html.

Nevin Institute 2013. Time for Tobin: Ireland and the European FTT Proposal. Dublin: NERI.

Passchier, C. 2014. 'New path for Europe, new model for Ireland'. Panel discussant, 'A new course for better times', Irish Congress of Trade Unions, 11 April, Round Room, Mansion House, Dublin.

Picketty, T. 2014. Capital in the $21^{\text {st }}$ Century, trans. Arthur Goldhammer. New York: Belknap Press.

Polanyi, K. 2001 [1944]. The Great Transformation: The Political and Economic Origins of Our Time. Boston: Beacon Press.

Sachs, W. 2013. 'Liberating the world from development', New Internationalist 460 (March).

Sainsbury, D. (ed.) 1999. Gender and Welfare State Regimes. Oxford: Oxford University Press.

Schultz, B. 2013. Overwhelmed: Work, Love, and Play When No One Has the Time. New York: Sarah Crichton Books.

Shaver, S. and J. Bradshaw. 1995. 'The recognition of wifely labour by welfare states', Social Policy and Administration 29(1): 10-25.

Slattery, L. 2014. 'Digest', Irish Times Business Section, 11 April, p. 4.

Smith, R. 2011. 'Green capitalism: the god that failed', Real World Economics Review 56:112-44.

Sorensen, K. and C. Bergqvist 2002. Gender and the Social Democratic Welfare Regime: A Comparison of Gender-Equality Friendly Policies in Sweden and Norway. Stockholm: National Institute for Working Life.

Trainer, T. 2010: 'A critical discussion of the Stern and IPCC analyses of carbon emission mitigation possibilities', Energy \& Environment 21(2): 49-73.

UNDP 2011. Human Development Report 2011: Sustainability and Equity. Basingstoke: Palgrave Macmillan.

United Nations Environmental Programme (UNEP). 2011. Towards a Green Economy: Pathways to Sustainable Development and Poverty Eradication. Nairobi: UNEP.

Ungar, B. 2013. 'How to finance a social Europe', pp. 95-98 in A. Grozelier, B. Hacker, W. Kowalsky, J. Machnig, H. Meyer and B. Unger (eds), Roadmap to a Social Europe. Brussels: ETUC.

Wright, E.O. 2013. 'Transforming capitalism through real utopias', American Sociological Review 78(1): 1-25. 